University of Nebraska - Lincoln

DigitalCommons@University of Nebraska - Lincoln

2006

Divergent patterns of abundance and age-class structure of headwater stream tadpoles in burned and unburned watersheds

Blake R. Hossack

Aldo Leopold Wildemess Research Institute

Paul Stephen Corn

Aldo Leopold Wildemess Research Institute

Daniel B. Fagre

Glacier National Park

Follow this and additional works at: https://digitalcommons.unl.edu/usgsstaffpub

Part of the Earth Sciences Commons

Hossack, Blake R.; Corn, Paul Stephen; and Fagre, Daniel B., "Divergent patterns of abundance and ageclass structure of headwater stream tadpoles in burned and unburned watersheds" (2006). USGS Staff -Published Research. 108.

https://digitalcommons.unl.edu/usgsstaffpub/108

This Article is brought to you for free and open access by the US Geological Survey at DigitalCommons@University of Nebraska - Lincoln. It has been accepted for inclusion in USGS Staff -- Published Research by an authorized administrator of DigitalCommons@University of Nebraska - Lincoln. 


\title{
Divergent patterns of abundance and age-class structure of headwater stream tadpoles in burned and unburned watersheds
}

\author{
Blake R. Hossack, Paul Stephen Corn, and Daniel B. Fagre
}

\begin{abstract}
Wildfire is a potential threat to many species with narrow environmental tolerances like the Rocky Mountain tailed frog (Ascaphus montanus Mittleman and Myers, 1949), which inhabits a region where the frequency and intensity of wildfires are expected to increase. We compared pre- and post-fire counts of tadpoles in eight streams in northwestern Montana to determine the effects of wildfire on A. montanus. All streams were initially sampled in 2001, 2 years before four of them burned in a large wildfire, and were resampled during the 2 years following the fire. Counts of tadpoles were similar in the two groups of streams before the fire. After the fire, tadpoles were almost twice as abundant in unburned streams than in burned streams. The fire seemed to have the greatest negative effect on abundance of age-1 tadpoles, which was reflected in the greater variation in same-stream age-class structure compared with those in unburned streams. Despite the apparent effect on tadpoles, we do not expect the wildfire to be an extirpation threat to populations in the streams that we sampled. Studies spanning a chronosequence of fires, as well as in other areas, are needed to assess the effects of fires on streams with A. montanus and to determine the severity and persistence of these effects.

Résumé : Les feux de brousse sont une menace potentielle à de nombreuses espèces à tolérance environnementale étroite et en particulier à la grenouille à queue des Rocheuses (Ascaphus montanus Mittleman et Myers, 1949) qui habite une région où les feux de brousse risquent d'augmenter en fréquence et en intensité à l'avenir. Nous avons comparé les dénombrements de têtards avant et après un feu dans huit cours d'eau du nord-ouest du Montana afin de déterminer les effets des feux de brousse sur $A$. montanus. Tous les cours d'eau ont été échantillonnés en 2001, 2 ans avant que quatre d'entre eux aient été affectés par un important feu de brousse, et ils ont tous été échantillonnés à nouveau 2 ans après le feu. Les dénombrements de têtards étaient semblables dans les deux groupes de cours d'eau avant le feu. Après le feu, les têtards étaient presque deux fois plus nombreux dans les cours d'eau non affectés par le feu que dans les cours d'eau affectés. Malgré cet effet apparent sur les têtards, nous ne comptons pas que les feux de brousse constituent une menace d'élimination des populations dans les cours d'eau que nous avons échantillonnés. Il faudrait mener des études couvrant une chronoséquence de feux et faire des recherches dans d'autres régions afin d'évaluer les effets sur les cours d'eau à A. montanus et pour déterminer la sévérité et la persistance des effets.
\end{abstract}

[Traduit par la Rédaction]

\section{Introduction}

Wildfire creates and maintains much of the structural diversity of forests in western North America (Hessburg and Agee 2003), and thus is an important factor in the distribution and abundance of most fauna (e.g., Smith 2000). There is, however, almost no information on the effects of wildfire on forest amphibians in the region, particularly in the Northwest (Corn et al. 2003; Bury 2004), where several endemic headwater stream species are sensitive to landscape disturbances (Corn and Bury 1989; Welsh 1990; Adams and Bury 2002). Effective management policies require better knowledge of direct and indirect effects of fire on amphib-

Received 20 April 2006. Accepted 28 August 2006. Published on the NRC Research Press Web site at http://cjz.nrc.ca on 1 December 2006.

B.R. Hossack ${ }^{1}$ and P.S. Corn. US Geological Survey, Aldo Leopold Wilderness Research Institute, 790 East Beckwith Avenue, Missoula, MT 59801, USA.

D.B. Fagre. US Geological Survey, Glacier Field Station, Glacier National Park, West Glacier, MT 59936, USA.

${ }^{1}$ Corresponding author (e-mail: blake_hossack@usgs.gov). ians, especially considering the recent outbreaks of large wildfires and projections of future fire scenarios in the region (Fagre et al. 2003; Westerling et al. 2006). Headwater stream amphibians, in particular, may be model candidates for indicators of ecosystem stress because their populations tend to be relatively stable and negative effects of disturbances are often unambiguous (Hairston 1987; Welsh and Ollivier 1998; Lowe et al. 2004).

The Rocky Mountain tailed frog (Ascaphus montanus Mittleman and Myers, 1949) is part of a large group of amphibians in the northwestern USA and southwestern Canada that often form the dominant vertebrate assemblage in forested headwater streams (Corn et al. 2003). Tadpoles of the more widely studied coastal tailed frog (Ascaphus truei Stejneger, 1899), the sister species of A. montanus (Nielson et al. 2001), are sensitive to disturbance-induced changes to stream habitats (Corn and Bury 1989; Welsh and Ollivier 1998). Limited research on environmental preferences and tolerances of A. montanus tadpoles (Franz and Lee 1970; Bull and Carter 1996; Adams and Frissell 2001) suggests that they are similar to those of A. truei. Ascaphus montanus may be particularly vulnerable to long-term decline after fire and other disturbances because its tadpoles require $>3$ years 
Fig. 1. Location of the eight study streams sampled for Ascaphus montanus and the 2003 Robert Fire in Glacier National Park and the Flathead National Forest, Montana, USA. The streams that were treated as burned for the analyses are underlined. The star between Apgar and Rubideau creeks indicates the approximate location of the Apgar fire lookout, where fire-control chemicals were applied.

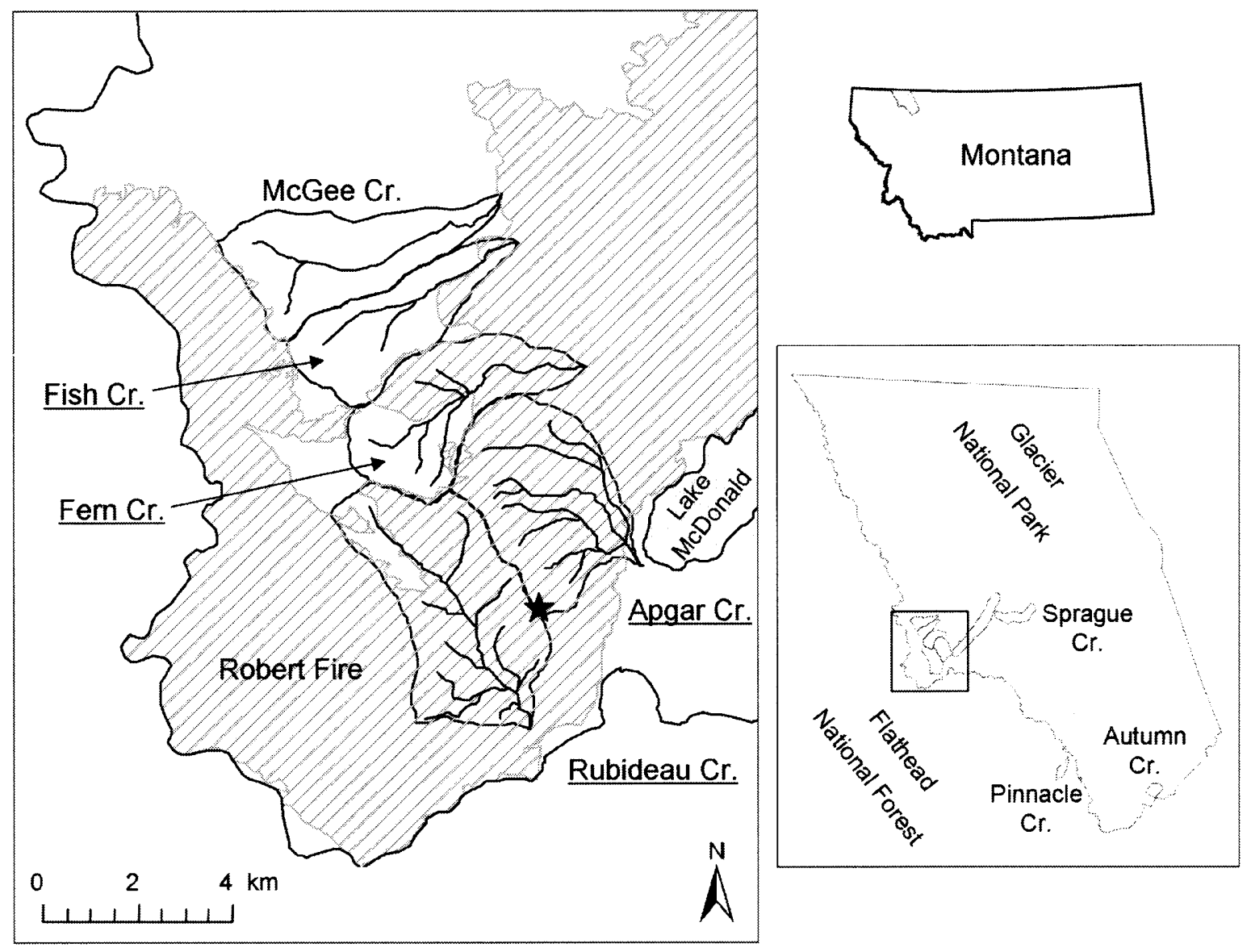

to metamorphose, females have delayed sexual maturity $(7$ 8 years) and low fertility ( $<100$ eggs biennially), and juveniles and adults are considered weak dispersers (Metter 1967; Daugherty and Sheldon 1982a, 1982b).

As part of an amphibian monitoring program in Glacier National Park (Corn et al. 2005; hereinafter "Glacier NP"), we evaluated a time-constrained sampling technique designed to detect presence of $A$. montanus tadpoles in 2001 in eight second- and third-order streams. Catchments of four of these eight streams burned in a 2003 wildfire, providing the rare opportunity of measuring the effects of wildfire by contrasting pre- and post-fire data in burned and unburned experimental units. By resampling the eight streams during the 2 years after the wildfire, we tested the hypotheses that fire reduced abundance and altered the ageclass structure of A. montanus tadpoles. Age ratios are not intrinsically linked with population size and must be interpreted cautiously because several vital rates can affect age ratios in similar ways. However, changes in age ratios can be used to help interpret population-level effects (Caughley 1974; McCullough 1994), and studies of stream salamanders (Gamradt and Kats 1997; Kerby and Kats 1998; Lowe et al. 2004) and fishes (Schlosser 1985; Jensen and Johnsen 1999) have documented age- or stage-specific responses to habitat changes.

\section{Materials and methods}

\section{Study area}

The human-caused Robert Fire started 23 July 2003 on the Flathead National Forest and entered the west side of Glacier NP later that day, burning ca. 16527 ha inside the park (Fig. 1; ca. 21398 ha total). Most of the study area was covered with dense stands of lodgepole pine (Pinus contorta Dougl. ex Loud.) and western larch (Larix occidentalis Nutt.) that regenerated after fires in the early $1900 \mathrm{~s}$ (Barrett et al. 1991). The historical fire frequency of these forests is $140-340$ years, which has not been altered greatly by fire-suppression efforts (Barrett et al. 1991). On three of four streams in the burned watersheds (hereinafter "burned streams"), the sampled reaches burned severely and little understory vegetation remained. The sampled reach on Apgar Creek was prevented from burning because it neighbors residential and administrative buildings that received firesuppression efforts. Characteristics of the burned and unburned watersheds were similar before the fire (Table 1), with the most notable exception being that Sprague Creek flows through a western redcedar (Thuja plicata Donn ex D. Don) - western hemlock (Tsuga heterophylla (Raf.) Sarg.) forest. Aerial drops of fire-control chemicals were applied immediately around the Apgar fire lookout (Fig. 1) to pre- 
Table 1. Mean and range (in parentheses) of watershed characteristics of the four burned and four unburned streams sampled for Ascaphus montanus tadpoles.

\begin{tabular}{lll}
\hline & \multicolumn{2}{l}{ Watershed status } \\
\cline { 2 - 3 } & Burned & Unburned \\
\hline Watershed size $\left(\mathrm{km}^{2}\right)$ & $9.9(6.9-13.3)$ & $8.8(5.0-15.4)$ \\
Watershed slope $(\%)$ & $9(7-10)$ & $10(7 \cdots 14)$ \\
Reach elevation $(\mathrm{m})$ & $1089(967-1223)$ & $1190(976-1470)$ \\
Percentage of watershed burned & $65(17-98)$ & $0^{a}(0$ to $<1)$ \\
Forest initiation date around sampled reach & $1895(1798-1929)$ & $1879(1769-1926)$ \\
\hline
\end{tabular}

${ }^{a}$ The fire burned just over the ridge at the top of the McGee Creek watershed $(<1 \%$ of the watershed area above the sampled reach).

vent it from burning, but they were not applied elsewhere in our study area (Dennis Divoky, Glacier NP fire ecologist, personal communication).

\section{Sampling}

The eight streams were originally sampled during June 2001. We sampled each stream by turning rocks and kicking through the substrate in front of D-frame nets for twentyfive 10 min periods, starting subsequent sampling periods immediately upstream of previous ones. Surveyors focused on areas of optimal habitat (e.g., turbulent water, coarse substrates) to increase the likelihood of capturing tadpoles. Two surveyors sampled simultaneously for $5 \mathrm{~min}$ each and called out their captures and estimated age (age-1, -2, or -3) of each tadpole to a data recorder. Embryos and age- 0 tadpoles (recently hatched) were also in the stream during summer sampling but were rarely found and were not considered part of the sampled population. Juveniles and adults used both stream and forest habitats and were not efficiently sampled during tadpole surveys.

We resurveyed the eight streams in 2004 and 2005, using the same methods and starting point as in 2001. All surveys were conducted after the peak of runoff of each year, corresponding to 15-18 June 2001, 28 June - 1 July 2004 (except for Rubideau Creek, which was surveyed on 26 July), and 6-9 July 2005. We are confident that the sampling effort was reasonably consistent among streams and years because the same person (B.R.H.) led the majority of the surveys.

We assessed inter-observer differences in designating tadpoles as either age- 1 or older in 2005 by having five samplers assign five tadpoles from each of the eight streams as either age- 1 or other. Of the 200 assignments, 198 concurred.

\section{Statistical analysis}

We used mixed-effects linear models to test the effect of the fire on square-root-transformed abundance of tadpoles in each stream. After the initial test on all tadpoles grouped together, we conducted secondary tests on age-1 tadpoles and older tadpoles separately to determine if the fire affected different tadpole stages equally. Only the age-1 year class was analyzed by itself because there is sometimes ambiguity in distinguishing age- 2 and age- 3 tadpoles at the time of year that we surveyed. Models included fixed-effects of treatment, year, and a year $\times$ treatment interaction term that was estimated using restricted maximum likelihood iterations. The interaction term tested whether there was a change in counts in burned streams after the fire relative to the trend in unburned streams (van Mantgem et al. 2001). An implicit assumption is that tadpole abundance in burned and unburned streams would have responded in the same manner to environmental variation in the absence of the fire (Wiens and Parker 1995). Data were grouped by stream and serial correlation was modeled with a compound symmetric covariance structure (Littell et al. 1996). Our sample size was too small to fit habitat covariates such as the percentage of watershed burned. We also measured stability of ageclass structure of tadpoles by calculating Pearson's correlation coefficients of the proportion of age- 1 tadpoles in each stream between sampling periods.

\section{Results}

In 2001, we found similar numbers of tadpoles in unburned streams and streams that would eventually burn (Fig. 2a). Tadpoles were more numerous in unburned streams after the fire, resulting in a significant year $\times$ treatment interaction term $\left(F_{[1,14]}=8.69, P=0.011\right)$. The fire seemed to affect the abundance of age-1 tadpoles (interaction term: $\left.F_{[1,14]}=11.89, P=0.004\right)$ more than the abundance of older tadpoles $\left(F_{[1,14]}=5.50, P=0.034\right)$, which was reflected in the greater reduction in the proportion of age-1 tadpoles in burned streams (Fig. 2b). Furthermore, the proportion of age-1 tadpoles within the same streams was more stable between sampling sessions in unburned streams than in burned streams. The proportions were strongly correlated in unburned streams (2001-2004: $r=0.95 ; 2004-2005$ : $r=0.99$ ), but were much weaker and were negatively correlated in burned streams (2001-2004: $r=-0.50,2004$ 2005: $r=0.10$ ). The mean proportion of age- 1 tadpoles was similar in burned stream in 2004 and 2005; however, there was greater between-year variation in the same streams. The largest reductions in proportion of age- 1 tadpoles were seen in Rubideau and Apgar creeks, the two watersheds that burned most severely.

\section{Discussion}

The expected increase in frequency and intensity of wildfires in the northern Rocky Mountains could affect many sensitive species (Fagre et al. 2003; Westerling et al. 2006), and the post-fire disparity in abundance of tadpoles suggests that $A$. montanus may be one of those species. Tadpoles were nearly twice as abundant in unburned streams than in burned streams during the 2 years after the wildfire, in con- 
Fig. 2. (a) Mean ( $\pm 1 \mathrm{SE})$ number of Ascaphus montanus tadpoles captured in four burned (shaded bars) and four unburned (unshaded bars) streams before and after the 2003 Robert Fire, and (b) mean proportion of age-1 tadpoles in burned (shaded bars) and unburned (unshaded) streams.

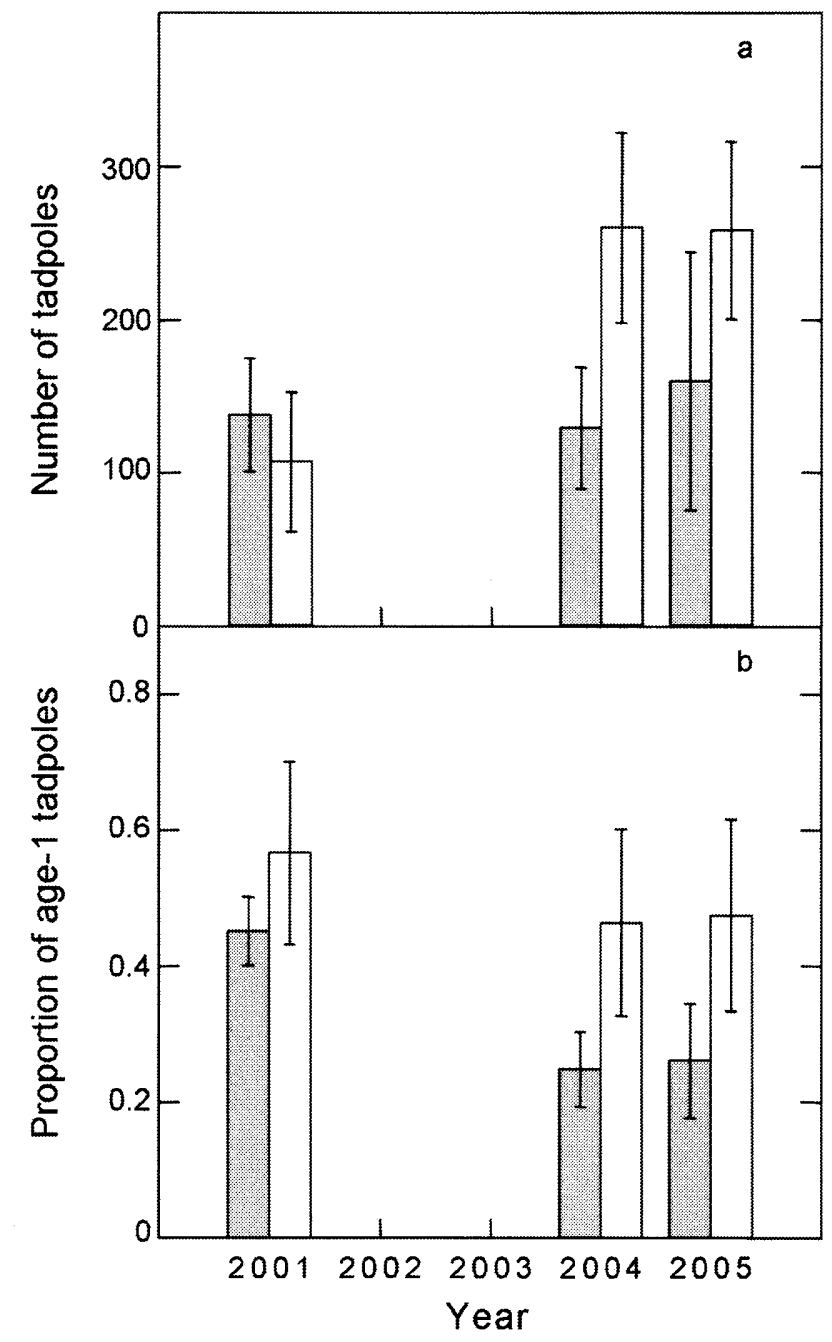

trast to similar counts before the fire. Increased water temperature and ammonia toxicity are two potential mechanisms that could have caused the difference in counts.

Increased temperature and ammonium concentrations often occur during intense fires and likely contributed to the death of numerous $A$. montanus adults and tadpoles in several third-order streams in northwestern Montana that burned in 1998 and 2001 (Pilliod et al. 2003). The maximum temperature increase recorded in three third-order streams with A. montanus in Glacier NP (larger than the ones we sampled) that burned in 2003, including Fish Creek (ca. $6 \mathrm{~km}$ downstream of where we sampled), was only $2.9 \mathrm{C}$ (D. Fagre, unpublished data). The following summer, however, temperature at the Fish Creek station increased $>5$ C relative to the year before the fire and exceeded the temperature limits of A. truei embryos (Brown 1975). The temperature of a third-order stream (Deadhorse Creek) near our study area increased rapidly by approximately 8 C during a 2001 wildfire (Hitt 2003). Aside from the potential for thermal stress, elevated temperatures in Deadhorse Creek could have increased the ammonia in solution by $16 \%-46 \%$ (Hitt 2003). Stream anmonium concentrations $(0.26 \mathrm{mg} / \mathrm{L}$ ) during a 1988 wildfire in Glacier NP (Spencer and Hauer 1991) exceeded the lethal limits of some salmonids (Russo 1985). The lethal ammonia concentration for A. montanus and most cold-water amphibians is unknown. Fire-control chemicals can also release levels of nitrogenous and cyanidebased products that are lethal to salmonids (Buhl and Hamilton 2000) and were applied in our study area near the Apgar fire lookout, located on the divide between Apgar and Rubideau creeks. However, unless there were undocumented applications nearer the study streams, we do not suspect that they affected our results.

The fire seemed to have a greater effect on younger tadpoles, evinced by the sharp drop in the count and proportion of age- 1 tadpoles in burned than in unburned streams. Age-1 tadpoles constituted only $25 \%$ of captures in burned streams during the 2 years after the fire compared with $45 \%$ before the fire. Repeated observations from tailed frog populations are rare, but data from 7 years of sampling two groups of streams in northern Idaho, where age- 1 tadpoles never constituted $<30 \%$ of total captures in either group (Lohman 2002; K. Lohman. USGS, personal communication), indicate that the change in age-class structure we found is unusual. Fewer age- 1 tadpoles is also consistent with preliminary results from surveys in burned watersheds elsewhere in the northern Rocky Mountains (Pilliod et al. 2004). Furthermore, the strong correlation in proportion of age-1 tadpoles between years in unburned streams is indicative of a stable breeding population (e.g., Hairston 1987), assuming survival from embryo to age- 1 tadpole was similar among years. Reduced survival of embryos and age- 0 tadpoles, which have lower temperature thresholds than older tadpoles (de Vlaming and Bury 1970; Brown 1975), and a reduced number of breeding adults are possible causes of the trend toward a smaller proportion and weaker between-sample correlation of age- 1 tadpoles in burned streams.

There are no published studies of the short-term response of stream amphibians to wildfire in the Northwest, but persistence of $A$. montants tadpoles in streams despite fire in the surrounding forest is consistent with studies of $A$. truei in streams affected by volcanic eruption (although not catastrophically) and forests naturally regenerated after wildfire. Ascaphus truei tadpoles were abundant in many streams in the blowdown zone of Mount St. Helens 5-7 years after its eruption, where the distribution of tadpoles was associated with the amount of forest remaining in each watershed (Hawkins et al. 1988; Crisafulli et al. 2005). The surviving forest stands likely provided protection from the blast effects and facilitated the rapid recovery seen in some streams (Crisafulli et al. 2005). Stream and terrestrial sampling of $A$. truei in naturally regenerated forests in Oregon and Washington indicated that if wildfire reduced its abundance or distribution, the reduction was not persistent because it was equally common in forests $30-50$ years old and forests $>200$ years old (Corn and Bury 1989; Bury et al. 1991). These patterns of recovery contrast with logging-related effects that can last for decades in some areas (Bury 2004; Ashton et al. 2005; Welsh et al. 2005). We suspect that we might have found a stronger effect of wildfire on $A$. 
montanus if we had sampled streams in managed lands, where populations might already be negatively affected by other disturbances, or in smaller streams that are more vulnerable to physical changes after a fire (Minshall et al. $2001)$.

Although it is possible that some of our results may be explained by spatial dependency (i.e., the burned streams were clustered, but the unburned streams were dispersed in a larger area; Fig. 1), the one unburned stream adjacent to the fire perimeter showed the same pattern of increased abundance as the other unburned streams, indicating that spatial dependence was unlikely. Studies of adult movement (Daugherty and Sheldon 1982b) and evidence of divergence of neighboring $A$. montanus populations in the same drainage (Daugherty 1979) also suggest that it is unlikely that local populations are synchronized through frequent exchange of adults. Instead, the concurrent increase in tadpole counts among four widely distributed streams implies that an environmental factor such as climate has a role in regulating population trends (e.g., Koenig 1999). The variation in counts among years also includes unquantified sampling variance, which is common to most studies of stream amphibians that only sample streams once per year (e.g., Corn and Bury 1989; Welsh and Ollivier 1998; Lohman 2002). Even though stream amphibians have lower annual variability in estimated abundance than pond-breeding amphibians (Green 2003), stream discharge at the time of surveys and other factors could affect capture efficiency. For example, Lohman (2002) reported a fourfold increase in density of A. montanus tadpoles across six sites in Idaho sampled during consecutive years.

Our study differs from most other Ascaphus studies in that we used the number of tadpoles captured as our abundance metric instead of estimated density. Because we did not originally intend to compare abundance between streams, we did not measure the amount of stream area sampled in 2001 and could not calculate density. However, tadpole abundance may provide a better index to size of the breeding population than density if the terrestrial environment is a stronger limiting factor on populations than the stream environment. For example, if the forest surrounding a first-order stream and a third-order stream both support a similar number of semi-terrestrial adults, the smaller stream may have greater density but fewer tadpoles. This nonlinear relationship between estimated density and abundance was illustrated for A. truei by Adams and Bury (2002), where tadpole density peaked at moderate stream widths (ca. $3 \mathrm{~m}$ ) but was similar at widths of ca. 1 and $4.5 \mathrm{~m}$. The relationship between abundance of tadpoles and adults is difficult to quantify, and presently, sufficient data are lacking to evaluate the link between these life stages or to evaluate the effects of population processes (e.g., survival, adult migration, tadpole drift) on patterns observed in the field for either Ascaphus species. We suggest that these relationships are important topics of future research that are necessary to truly gauge the effects of disturbances on populations.

Considering the continued recruitment in all four burned streams along with remnants of surviving forest in each burned watershed, the rapid recovery of streamside shrubs, and the seemingly small changes to the stream channels, we do not suspect that the wildfire is a threat to extirpate
A. montanus in the streams that we sampled. On an evolutionary timescale, wildfire has been a frequent disturbance to $A$. montanus, so persistence in relatively undisturbed streams should not be surprising. Fire may actually provide some benefits over longer time periods if adverse effects on adults and the stream channel are not severe. Stream communities in Glacier NP shifted toward greater autotrophy during the 4-5 years after burning in a 1988 wildfire (Spencer et al. 2003), and increased photosynthetic production can result in higher growth rates and survival by resource-limited $A$. truei tadpoles that graze on periphyton (Kiffney and Richardson 2001; Mallory and Richardson 2005).

Conversely, the full extent of population-level effects may not be evident immediately after a disturbance. Pilliod et al. (2003) hypothesized a response curve for amphibians such as $A$. montanus that showed little immediate effect of wildfire followed by decline a few years later, a pattern consistent with life-history theory that suggests survival of adults may be a more critical vital rate than survival of tadpoles (sensu Pianka 1970). A delayed decline after disturbance could be expected from changes in terrestrial habitat that reduce survival or increase emigration of juveniles and adults (Bury et al. 1991; Matsuda and Richardson 2005), as well as from persistent habitat changes that reduce tadpole survival and recruitment into the breeding population. It will be important to monitor A. montanus tadpoles and stream characteristics for $>2$ years after the wildfire because vulnerability to change in the physical and biological characteristics of streams can persist for many years and because effects on the long-lived adults are unknown.

\section{Acknowledgements}

Funding was provided by the US Geological Survey through the Amphibian Research and Monitoring Initiative and the Global Change Research Program. We thank B. Davis, C. Key, D. Divoky, K. Holzer, R. King, and S. Schwartz for their contributions to the study. Comments by A. Sheldon, B. Bury, D. Pilliod, W. Lowe, C. Spencer, and an anonymous reviewer improved the manuscript.

\section{References}

Adams, M.J., and Bury, R.B. 2002. The endemic headwater stream amphibians of the American Northwest: associations with environmental gradients in a large forested preserve. Glob. Ecol. Biogeogr. 11: 169-178. doi:10.1046/j.1466-822X.2002.00272.x.

Adams, S.B., and Frissell, C.A. 2001. Thermal habitat use and evidence of seasonal migration by Rocky Mountain tailed frogs, Ascaphus montanus, in Montana. Can. Field Nat. 115: 251-256.

Ashton, D.T., Marks, S.B., and Welsh, H.H. Jr. 2005. Evidence of continued effects from timber harvesting on lotic amphibians in redwood forests of northwestern California. For. Ecol. Manag. 221: $183-193$.

Barrett, S.W., Arno, S.F., and Key, C.H. 1991. Fire regimes of western larch - lodgepole pine forests in Glacier National Park, Montana. Can. J. For. Res. 21: 1711-1720.

Brown, H.A. 1975. Temperature and development of the tailed frog, Ascaphus truei. Comp. Biochem. Physiol. A, 50: 397-405. doi:10.1016/0300-9629(75)90033-X. PMID:234352.

Buhl, K.J., and Hamilton, S.J. 2000. Acute toxicity of fire-control chemicals, nitrogenous chemicals, and surfactants to rainbow 
trout. Trans. Am. Fish. Soc. 129: 408 418. doi:10.1577/1548$8659(2000) 129<0408$ : ATOFCC $>2.0 . \mathrm{CO}: 2$.

Bull, E.L., and Carter, B.E. 1996. Tailed frogs: distribution, ecology, and association with timber harvest in northeastern Oregon. U.S. For. Serv. Res. Pap. PNW No. RP-497. pp. 1-12.

Bury, R.B. 2004. Wildfire, fuel reduction, and herpetofaunas across diverse landscape mosaics in northwestern forests. Conserv. Biol. 18: 968-975. doi:10.1111/j.1523-1739.2004.00522.x.

Bury, R.B., Corn, P.S., Aubry, K.B., Gilbert, F.F., and Jones, L.L.C. 1991. Aquatic amphibian communities in Oregon and Washington. In Wildlife and vegetation of unmanaged Douglasfir forests. Edited by L.F. Ruggiero, K.B. Aubry, A.B. Carey, and M.H. Huff. U.S. For. Serv. Gen. Tech. Rep. PNW No. GTR-285. pp. $353-362$.

Caughley, G. 1974. Interpretation of age ratios. J. Wildl. Manag. 38: $557-562$.

Corn, P.S., and Bury, R.B. 1989. Logging in western Oregon: responses of headwater habitats and stream amphibians. For. Ecol. Manag. 29: 39-57.

Corn, P.S., Bury, R.B., and Hyde, E.J. 2003. Conservation of North American stream amphibians. In Amphibian conservation. Edited by R.D. Semlitsch. Smithsonian Books, Washington. pp. 24-36.

Corn, P.S., Hossack, B.R., Muths, E., Patla, D.A., Peterson, C.R., and Gallant, A.L. 2005. Status of amphibians on the Continental Divide: surveys on a transect from Montana to Colorado. Alytes, 22: 85-94.

Crisafulli, C.M., Trippe, L.S., Hawkins, C.P., and MacMahon, J.A. 2005. Amphibian responses to the 1980 eruption of Mount St. Helens. In Ecological responses to the 1980 eruption of Mount St. Helens. Edited by V.H. Dale, F.J. Swanson, and C.M. Crisafulli. Springer-Verlag, New York. pp. 183-197.

Daugherty, C.H. 1979. Population ecology and genetics of Ascaphus truei: an examination of gene flow and natural selection. Ph.D. thesis, University of Montana, Missoula.

Daugherty, C.H., and Sheldon, A.L. 1982a. Age-determination, growth, and life history of a Montana population of the tailed frog (Ascaphus truei). Herpetologica, 38: 461-468.

Daugherty, C.H., and Sheldon, A.L. 1982b. Age-specific movement patterns of the frog Ascaphus truei. Herpetologica, 38: 468 474 .

de Vlaming, V.L., and Bury, R.B. 1970. Thermal selection in tadpoles of the tailed frog, Ascaphus truei. J. Herpetol. 4: 179-189. doi: $10.2307 / 1562892$.

Fagre, D.B., Peterson, D.L., and Hessl, A.E. 2003. Taking the pulse of mountains: ecosystem responses to climatic variability. Clim. Change, 59: 263-282. doi:10.1023/A:1024427803359.

Franz, R., and Lee, D.S. 1970. The ecological and biogeographical distribution of the tailed frog, Ascaphus truei, in the Flathead River drainage of northwestern Montana. Bull. Md. Herpetol. Soc. 6: $62-73$.

Gamradt, S.C., and Kats, L.B. 1997. Impact of chaparral wildfireinduced sedimentation on oviposition of stream-breeding California newts (Taricha torosa). Oecologia (Berl.), 110: 546-549. doi:10.1007/s004420050193.

Green, D.M. 2003. The ecology of extinction: population fluctuation and decline in amphibians. Biol. Conserv. 111: 331-343. doi:10.1016/S0006-3207(02)00302-6.

Hairston, N.G., Jr. 1987. Community ecology and salamander guilds. Cambridge University Press, New York.

Hawkins, C.P., Gottschalk, L.J., and Brown, S.S. 1988. Densities and habitat of tailed frog tadpoles in small streams near Mt. St. Helens following the 1980 eruption. J. North Am. Benthol. Soc. 7: 246-252. doi: $10.2307 / 1467424$.

Hessburg, P.F., and Agee, J.K. 2003. An environmental narrative of inland northwest United States forests, 1800-2000. For. Ecol. Manag. 178: 23-59.

Hitt, N.P. 2003. Immediate effects of wildfire on stream temperature. J. Freshw. Ecol. 18: 171-173.

Jensen, A.J., and Johnsen, B.O. 1999. The functional relationship between peak spring floods and survival and growth of juvenile Atlantic Salmon (Salmo salar) and Brown Trout (Salmo trutta). Funct. Ecol. 13: 779-785.

Kerby, J.L., and Kats, L.B. 1998. Modified interactions between salamander life stages caused by wildfire-induced sedimentation. Ecology, 79: 740-745. doi:10.2307/176967.

Kiffney, P.M., and Richardson, J.S. 2001. Interactions among nutrients, periphyton, and invertebrate and vertebrate (Ascaphus truei) grazers in experimental channels. Copeia, 2001: 422429. doi:10.1643/0045-8511(2001)001[0422:IANPAI]2.0.CO;2.

Koenig, W.D. 1999. Spatial autocorrelation of ecological phenomena. Trends Ecol. Evol. 14: 22-26. doi:10.1016/S0169-5347(98) 01533-X. PMID:10234243.

Littell, R.C., Milliken, G.A., Stroup, W.W., and Wolfinger, R.D. 1996. SAS system for mixed models. SAS Institute Inc., Cary, N.C.

Lohman, K. 2002. Annual variation in the density of stream tadpoles in a northern Idaho (USA) watershed. Verh. Int. Ver. Limnol. 28: 1-5.

Lowe, W.H., Nislow, K.H., and Bolger, D.T. 2004. Stage-specific and interactive effects of sedimentation and trout on a headwater stream salamander. Ecol. Appl. 14: 164-172.

Mallory, M.A., and Richardson, J.S. 2005. Complex interactions of light, nutrients and consumer density in a stream periphytongrazer (tailed frog tadpoles) system. J. Anim. Ecol. 74: 1020 1028. doi:10.1111/j.1365-2656.2005.01000.x.

Matsuda, B.M., and Richardson, J.S. 2005. Movement patterns and relative abundance of coastal tailed frogs in clearcuts and mature forest stands. Can. J. For. Res. 35: 1131-1138. doi:10. 1139/x05-042.

McCullough, D.R. 1994. What do herd composition counts tell us? Wildl. Soc. Bull. 22: 295-300.

Metter, D.E. 1967. Variation in the ribbed frog Ascaphus truei Stejneger. Copeia, 1967: 634-649. doi:10.2307/1442243.

Minshall, G.W., Royer, T.V., and Robinson, C.T. 2001. Response of the Cache Creek macroinvertebrates during the first 10 years following disturbance by the 1988 Yellowstone wildfires. Can. J. Fish. Aquat. Sci. 58: 1077-1088. doi:10.1139/cjfas-58-6-1077.

Nielson, M., Lohman, K., and Sullivan, J. 2001. Phylogeography of the tailed frog (Ascaphus truei): implications for the biogeography of the Pacific Northwest. Evolution, 55: 147160. doi:10.1554/0014-3820(2001)055[0147:POTTFA]2.0.CO;2. PMID:11263735.

Pianka, E.R. 1970. On $r$ - and K-selection. Am. Nat. 104: 592-597. doi: $10.1086 / 282697$.

Pilliod, D.S., Bury, R.B., Hyde. E.J., Pearl, C.A., and Corn, P.S, 2003. Fire and amphibians in North America. For. Ecol. Manag. 178: $163-181$.

Pilliod, D.S., Corn, P.S., Bury, R.B., and Hyde, E.J. 2004. Effects of wildland fires on stream amphibian populations in the greater Northwest. Northwest. Nat. 85: 85-86. [Abstract.]

Russo, R.C. 1985. Ammonia, nitrite, and nitrate. In Fundamentals of aquatic toxicology. Edited by G.M. Rand and S.R. Petrocelli. Hemisphere Publishing Corp., New York. pp. 455471.

Schlosser, IJJ. 1985. Flow regime, juvenile abundance, and the assemblage structure of stream fishes. Ecology, 66: 14841490. doi:10.2307/1938011.

Smith, J.K. (Editor). 2000. Wildland fire in ecosystems: effects of fire on fauna. Vol. 1. U.S. For. Serv. Gen. Tech. Rep. No. RMRS-GTR-42. 
Spencer, C.N., and Hauer, F.R. 1991. Phosphorus and nitrogen dynamics in streams during a wildfire. J. North Am. Benthol. Soc. 10: 24 30. doi: $10.2307 / 1467761$.

Spencer, C.N., Gabel, K.O., and Hauer, F.R. 2003. Wildfire effects on stream webs and nutrient dynamics in Glacier National Park, USA. For. Ecol. Manag. 178: 141-153.

van Mantgem, P., Schwartz, M., and Keifer, M. 2001. Monitoring fire effects for managed burns and wildfires: coming to terms with pseudoreplication. Nat. Areas J. 21: 266-273.

Welsh, H.H., Jr. 1990. Relictual amphibians and old-growth forests. Conserv. Biol. 4: 309-319.

Welsh, H.H., Jr., and Ollivier, L.M. 1998. Stream amphibians as indicators of ecosystem stress: a case study from California's redwoods. Ecol. Appl. 8: 1118-1132.

Welsh, H.H., Jr., Hodgson, G.R., and Lind, A.J. 2005. Ecogeography of the herpetofauna of a northern California watershed: linking species patterns to landscape processes. Ecography, 28: 521-536.

Westerling, A.L., Hidalgo, H.G., Cayan, D.R., and Swetnam, T.W. 2006. Warming and earlier spring increases western U.S. forest fire activity. Science (Washington, D.C.), 313: 940-943. doi:10. 1126/science. 1128834 . PMID: 16825536.

Wiens, J.A., and Parker, K.A. 1995. Analyzing the effects of accidental environmental impacts: approaches and assumptions. Ecol. Appl. 5: 1069-1083. 